Zbigniew J. Żótciński

Katedra Historii Wychowania,

Wydziat Nauk Pedagogicznych,

Akademia Pedagogiki Specjalnej im. A. Grzegorzewskiej w Warszawie

\title{
Zróżnicowane ramy prawne ojcowskiej władzy rodzicielskiej obowiązujące na ziemiach polskich w pierwszej połowie XIX wieku
}

\begin{abstract}
Different ranges of paternal power according to binding regulations existing in Polish territories in the first half of the 19th century

The law itself has a proven impact on people's everyday lives. It is usually the product of compromise, which also reflects the culture of its times. Private law of 19th century was no exception. This study shows that political partitions of Poland has divided also polish perception of family and fatherhood. This work examines the problem of parallel visions of polish fatherhood through the lens of the early civil law codifications. New private laws were starting point for a change in paternal power. These modernization has had their own speed and energy separate in each partition area. Focusing on paternity as a category of family history, this article shows the changing borders of paternal power and responsibility which brings new approach to understanding of how private acts were governed by laws of the state.
\end{abstract}

Keywords: fatherhood, codification, family, private law, 19th century

Prawo jest znakomitym, choć specyficznym źródłem do historii wychowania. Z jednej strony cały system prawny jest zwierciadłem rzeczywistości społecznej, z drugiej, warto mieć na uwadze to, że syntetyczny obraz rzeczywistości wyłaniający się z tego źródła zazwyczaj jest rodzajem kompromisu, pewną syntezą.

Nawet spisy prawa zwyczajowego dla danej dzielnicy Rzeczypospolitej musiały być w jakimś stopniu ujednolicane, a ostateczny kształt musiał odpowiadać szeroko pojętemu ośrodkowi władzy, jak i być zgodny z utrwaloną tradycją. Notoryczne odrzucanie wielu statutów prawa w dobie I Rzeczypospolitej czy to przez panującego, czy przez rzesze szlachty, pokazuje z jak delikatną materią mamy do czynienia. Zagadnienie kompromisu i syntezy dotyczy także prawa małżeńskiego i rodzinnego, które były częścią prawa prywatnego, a więc przez długi czas nawet nie były w kręgu zainteresowania państwa, co też powodowało, w tym zakresie, trwałe współistnienie różnic stanowych, terytorialnych i wyznaniowych. 
Przepisy prawa ponadto są w swej istocie wielofunkcyjne ${ }^{1}$. W nauce nie utrwalit się dotychczas jednolity poglad na temat typologii funkcji prawa. Stąd w literaturze prawniczej znajdziemy próby typologii uwzględniające rozmaite kryteria podziału ${ }^{2}$. Za szczególnie istotne dla ukazania obrazu ojcowskiej władzy rodzicielskiej warto wyróżnić funkcje: organizacyjną, dynamizującą, stabilizacyjną i wychowawczą. Przypomnienie poszczególnych funkcji może pomóc we właściwej interpretacji źródeł prawa i właściwym zrozumieniu obrazu władzy ojcowskiej wyłaniającej się z przepisów.

Funkcja organizacyjna, najbardziej oczywista często jest uważana za nadrzędną, polega na organizacji społeczeństwa, regulacji różnych sfer życia społecznego i zabezpieczeniu przestrzegania prawa w celu osiągnięcia zgodności z zasadami ustroju i chronionymi wartościami. Przepisy prawa rodzinnego organizują i regulują to życie rodzinne i dlatego są dla nas tak cenne jako źródło historyczne.

Funkcja stabilizująca ma za zadanie zagwarantować ład, bezpieczeństwo i utrzymać istniejący układ stosunków społecznych. Przepisy prawa mają więc za zadanie zlikwidować potencjalne konflikty i rozładować mogące się pojawić zagrożenia. Wiedząc o tym, przy interpretacji władzy ojcowskiej warto pamiętać, że prawo nie reguluje każdego aspektu życia społecznego. Skupia się na sytuacjach skrajnych, konfliktowych, ma za zadanie przewidzieć i rozładować. Obraz wyłaniający się ze źródeł prawa jest więc z reguły wybiórczy i mówi więcej o dysharmonii życia rodzinnego, konfliktach, poważnych sytuacjach spornych, niż o przeciętnym, zrównoważonym życiu codziennym. Ten drugi wariant ze względu na brak znacznej społecznej szkodliwości jest poza zainteresowaniem prawa. Przy czym znów trzeba pamiętać, że wiele z pojęć jak „,szkodliwość” jest zmienna znaczeniowo tak w czasie, jak i terytorialnie.

Często cechą przepisów, choć nie wszystkich jest funkcja dynamizująca, która wyraża się w wprowadzaniu zmian w układzie i kształtowaniu nowych stosunków społecznych. Interpretacja, kiedy w danym prawie przeważa funkcja stabilizująca, a kiedy dynamizująca wymaga sięgnięcia do wiedzy pozaźródłowej. Podczas uchwalania „obalenia” władzy ojcowskiej we Francji w 1792 r. z pewnością przepisy te charakteryzowały się przewagą funkcji skrajnie dynamizującej, podczas gdy przywrócenie władzy ojców w Kodeksie Cywilnym z 1804 r. spełniało zadania stabilizacji stosunków społecznych.

Funkcja wychowawcza polega na ksztaltowaniu pozytywnych postaw wobec prawa $i$ to zarówno wobec prawa traktowanego jako wartość samoistna, sama $w$ sobie (tad społeczny, legalność, praworzadność i zwiąana z tym pewność prawa i przewidywalność wyników jego stosowania), jak $i$ wobec poszczególnych norm prawnych, wyznaczajacych określone postępowanie i stanowiacych wyraz preferencji i ochrony takich wartości jak

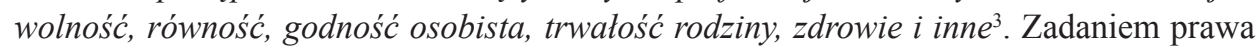

\footnotetext{
1 Wykorzystano tezy zawarte w pracy: M. Borucka-Arctowa, Społeczne funkcje prawa formułowane $w$ doktrynie, ustawodawstwie i orzecznictwie, w: Spoleczne poglady na funkcje prawa, red. M. Borucka-Arctowa, Wrocław 1982 s. 13-24.

2 T. Stawecki, P. Winczorek, Wstęp do prawoznawstwa, Warszawa 1999, s. 11.

${ }^{3}$ M. Borucka-Arctowa, op. cit., s. 21.
} 
jest wyrobienie w adresatach norm trwałych przekonań, skłonności nawyków ${ }^{4}$. Przepisy niosą ze sobą też pewne oczekiwania i postulaty, wyznaczają pewne standardy i wzorce. W przepisach zawarty jest więc system wartości w stabilnych warunkach akceptowany, bądź mający być zaakceptowany przez społeczeństwo. Leon Petrażycki, uznany teoretyk prawa, przypisywał nawet dobrze skonstruowanemu prawu, że może ono wytworzyć lub przyspieszyć postęp moralny społeczeństwa ${ }^{5}$.

Przepisy oddziatuja na społeczeństwo wychowawczo już przez sam fakt ich obowiazywania. Konieczna jest jednak świadomość prawna, a więc znajomość treści tego pra$w a^{6}$. Nieznajomość prawa nie zwalnia ze stosowania się do niego, ale musimy mieć świadomość, że rzeczywistość tak dzisiaj, jak i w przeszłości (przy znacznie mniejszej objętości obowiązującego prawa, ale i rzadziej dostępnej edukacji i większym stopniu analfabetyzmu) stanowi duży problem.

Funkcja wychowawcza nie zawsze też spełnia pokładane przez prawodawców nadzieje. Kodeks Napoleona wprowadził na terenie Księstwa Warszawskiego i dalej Królestwa Polskiego instytucję świeckiego małżeństwa i rozwodu. Do 1818 r. odbyły się tylko trzy śluby bez sakramentu, zaś rozwodów orzeczonych wyłącznie przez sądy państwowe było siedem ${ }^{7}$.

Mając zatem na uwadze skomplikowany i delikatny charakter źródeł prawa, niniejszy przyczynek nie rości sobie pretensji do przedstawienia pełnego obrazu władzy rodzicielskiej ojca, a jedynie naszkicowanie ram, w oparciu o które władza ta działała. Powinien jednak przybliżyć ducha praw tzw. wielkich kodyfikacji, w których to polu zainteresowań pojawiła się ojcowska władza rodzicielska.

W następstwie zaborów i wojen napoleońskich na ziemiach polskich obowiązywały różniące się między sobą porządki prawne. Dotyczyło to także prawa cywilnego, także jego części zwanej prawem rodzinnym. Wielkie kodyfikacje prawa cywilnego dojrzały do powstania na przełomie XVIII i XIX w. Powstały one na skutek przeniknięcia filozofii prawa natury do myśli państwowej epoki oświecenia. Zasady rozumu i naturalnego porządku miały stanowić system nadrzędny. Według niego należało budować porządek społeczny. Wizja owego porządku była wywodzona z ogólnych, poznawalnych rozumem praw przyrody, której częścią był człowiek. Prawo miało być świeckie, uniwersalne, jako cel stawiać sobie powinno służbę dobru ogólnemu. Prawo natury czasów oświecenia wywarło bezpośredni wpływ na ustawodawstwo, było podstawą ideologiczną i uzasadnieniem kodyfikacji cywilnych. Z owymi założeniami musiało iść w parze ujednolicenie obowiązującego prawa oraz poszerzenie dziedziny, którą normowało. Szczegółowa regulacja, rozszerzenie prawa na wszystkie stany zaistniały także na gruncie prawa rodzinnego, co pozwala z kolei na próbę odtworzenia pozycji samego ojca w oparciu o obowiązujące prawo.

\footnotetext{
${ }^{4}$ T. Stawecki, P. Winczorek, op. cit., s. 11.

${ }^{5}$ Por. L. Petrażycki Wstęp do nauki polityki prawa, Warszawa 1968, s. 29-59.

${ }^{6}$ W. Stojanowska, Wychowawcze treści prawa rodzinnego, w: Prawo $i$ Wychowanie, red. T. Leśko, Warszawa 1985, s. 38.

7 J. Bardach, B. Leśnodorski, M. Pietrzak, Historia ustroju i prawa polskiego, Warszawa 2000, s. 418.
} 


\section{Sytuacja pod jurysdykcją pruską}

W Prusach tempo prac nad kodyfikacją prawa wzrosło w wyniku zaboru ziem polskich i potrzeby ujednolicenia prawa na nowych terenach. Wcześniej prace nad nowoczesnym kodeksem podjęte były za panowania Fryderyka II Wielkiego. Pierwsza bezpośrednia inicjatywa tego oświeconego, absolutnego monarchy zaowocowała mało nowatorskim zbiorem Corpus Iuris Fridericiani ${ }^{8}$. Samuel Cocceji, minister sprawiedliwości i kanclerz Prus, który czuwał nad tym dziełem, nie stworzył nowoczesnego kodeksu, ale zebrał całe obowiązujące w Prusach prawo. Podobny zbiór w sąsiedniej Rosji powstał dopiero w 1830 r. ${ }^{9}$ Druga inicjatywa Fryderyka Wielkiego zakończyła się już po jego śmierci. Po publicznej dyskusji i cofnięciu niektórych zbyt daleko idących zmian opublikowano bardzo obszerny kodeks pod nazwą Allgemeines Landrecht für die Königlich Preussischen Staaten $^{10}$. Obszerny, liczący $19187^{11}$ paragrafów zbiór zawierał przepisy prawa państwowego, lennego, kościelnego, prywatnego handlowego i in. Miał obejmować całość prawa obowiązującego na terenie Prus, ale miał charakter subsydiarny ${ }^{12} \mathrm{w}$ stosunku do praw prowincjonalnych. Kodeks miał być powszechnie zrozumiały, dokładny, bez luk, tak by funkcje sędziów ograniczały się do zastosowania odpowiedniego do sytuacji przepisu. Żaden z tych postulatów nie został do końca spełniony, niemniej jednak Landrecht był bardzo udaną kodyfikacją, o czym świadczy ponadstuletnie jej użytkowanie ${ }^{13}$. W swych założeniach nawiązywał do dzieła De jure naturae et gentium Samuela Pufendorfa ${ }^{14}$, w którym przedstawiano człowieka w podwójnym charakterze: jako jednostkę i członka społeczności. Landrecht również dzieli się na dwie części. Pierwsza z nich dotyczy praw indywidualnych jednostki do rzeczy, druga praw społecznych, a więc praw jednostki wobec organizmów społecznych. Nie odpowiada ten podział dzisiejszej systematyce prawa. Interesujące nas prawo rodzinne zawierało się w części drugiej ${ }^{15}$.

O ile powszechne prawa ludzkości należały się wszystkim łącznie z dziećmi od chwili poczęcia ${ }^{16}$, o tyle prawa nabyte uzyskiwało się w kilku etapach. Do ukończenia siódmego roku życia uważano wszystkich za dzieci, niedorosłymi były osoby do lat czternastu. Bez różnicy miejsca pochodzenia i stanu małoletniość trwała aż do skończenia dwudziestego czwartego roku życia. Ciekawe jest, że ludzi szalonych i obłąkanych zrów-

${ }^{8}$ Spośród 3 części opublikowano pierwszą w 1749 i drugą w 1751 r., a ostatniej zaniechano.

9 Pełny Zbiór Praw Cesarstwa Rosyjskiego obejmujący ustawodawstwo od 1649 do 1825 r.

${ }^{10}$ Powszechne Prawo Krajowe dla Państw Królewsko-pruskich.

${ }^{11}$ K. Sójka-Zielińska, Wielkie kodyfikacje cywilne XIX wieku, Warszawa 1973, s. 28.

12 S. Salmonowicz, Prawo karne oświeconego absolutyzmu z dziejów kodyfikacji karnych przełomu XVIII i XIX wieku, Toruń 1966, s. 214. Od roku 1797 miał charakter w pełni obowiązującego prawa; vide: S. Płaza, Historia prawa w Polsce na tle porównawczym, t. II, Kraków 2002, s. 49.

13 Obowiązywał od $1794 \mathrm{r}$. do 1900 , na ziemiach polskich od $1797 \mathrm{r}$.

${ }^{14}$ Pierwsze wydanie: Samuel Pufendorf, De jure naturae et gentium, Lund 1672.

15 K. Sójka-Zielińska, op.cit., s. 29.

${ }^{16}$ Allgemeines Landrecht fur die Koniglich Preussischen Staaten (ALR) 1794, cz. I, tytuł I: „O osobach i ich prawach w ogólności”, art. 10 w: G. Bałtruszajtis, J. Kolarzowski, M. Paszkowska, K. Rajewski (red.), Wybór źródet do historii prawa sądowego czasów nowożytnych, Warszawa 1996, s. 58. 
nano w prawach z dziećmi, zaś niedołężnych na umyśle i sądownie uznanych za marnotrawców, w prawach z małoletnimi ${ }^{17}$. Dzieci więc uważano za zupełnie niezdolne do samodzielnych czynów, niedorozwinięcie małoletnich zrównywano z upośledzeniem umysłowym dorosłych. Mimo że w rozdziale „O osobach i ich prawach w ogólności” paragraf 24 stanowił: Prawa ptci obydwóch sa sobie równe, ile oddzielne ustawy lub prawnie ważne oświadczenia woli w tym wyjątku nie stanowiq ${ }^{18}$, to dominująca pozycja męża, ojca jasno wyrażała się w przepisach prawa rodzinnego. Tak jak oficerowie będący w czynnej służbie wojskowej gdy chcieli wstąpić w związek małżeński, musieli o zgodę prosić króla, tak dzieci niezależnie od wieku o podobną zgodę musiały prosić ojca ${ }^{19}$. Ale małżeństwa zawarte powyżej 24. roku życia przez córkę i przez syna, który wyszedł spod władzy ojcowskiej, wbrew woli ojca zostawały ważne ${ }^{20}$. Tylko wtedy małżeństwo mogło być ważne. Małżeństwo dopuszczano dla mężczyzn od osiemnastego, a dla kobiet od czternastego roku życia. Dopiero w wypadku braku ojca, małoletni musieli pytać o zgodę matkę, a gdyby i jej brakowało - dziadów.

Wyraźnie zostało zaznaczone, że w małżeństwie głową rodziny jest mąż ${ }^{21}$. On też reprezentował rodzinę w sądzie, bez jego zgody żona sądzić się nie mogła. W momencie zawarcia małżeństwa, jeśli nie było intercyzy, majątek żony przechodził pod zarząd mę$\dot{z ̇}^{22}$. Przywileje decyzyjne łączyły się z obowiązkami. Mą̇ ma obowiązek i prawo bronienia osoby, sławy i majątku swej żony, w sadzie i zasądownie ${ }^{23}$. Obowiąany jest żone stosownie utrzymywac ${ }^{24}$. W większości reszty przepisów dotyczących samego małżeństwa mąż i żona traktowani są jednakowo, jednak ogół praw i obowiązków nie pozostawia wątpliwości, że to mąż był precyzyjnie wyrażonym ośrodkiem decyzyjnym w małżeństwie, a jego obowiązki były zbyt ogólnie sprecyzowane, by zrównoważyć tak szerokie kompetencje. W niektórych przepisach zaś posiadał większą niż żona, niczym nieusprawiedliwioną swobodę, jak w przepisie o żałobie. Wdowa niech rok cały, a wdowiec pót roku odprawi żałobę za zmarłego matżonka ${ }^{25}$.

Z punktu widzenia naszych zainteresowań najważniejsze są jednak przepisy dotyczące relacji dzieci z rodzicami. Zajmując się małżeństwami zawartymi „na prawą rękę”, a więc w pełni legalnymi między osobami tego samego stanu, trzeba wspomnieć, że rozróżniano małżeństwa na lewą rękę, gdzie ani żona, ani dzieci nie dziedziczyły nazwiska i stanu ojca, ale pod innymi względami, w tym dziedziczenia, były zrównane z dziećmi z małżeństwa na prawą rękę. Dlatego oba przypadki będą omawiane wspólne. Inaczej się miało z dziećmi pozamałżeńskimi. Ich sytuacja była o wiele gorsza niż legalnych

\footnotetext{
17 Ibidem, art. 25-31, s. 59.

18 Ibidem, art. 24, s. 58.

19 Ibidem, część II, tytuł I „O małżeństwie”, art. 34 i 45-46, s. 73.

${ }^{20}$ Ibidem, część II, tytuł I „O małżeństwie”, art. 997, s. 76.

21 Ibidem, część II, tytuł I „O małżeństwie”, art. 184, s. 76.

22 Ibidem, część II, tytuł I „O małżeństwie”, art. 205, s. 74.

${ }^{23}$ Ibidem, część II, tytuł I: „O małżeństwie”, art. 188, s. 74.

${ }^{24}$ Ibidem, część II, tytuł I: „O małżeństwie”, art. 185, s. 74.

25 Ibidem, część II, tytuł I: „O małżeństwie”, art. 436, s. 75.
} 
dzieci. Nie wchodziły do familii ani ojca, ani matki, opiekę nad nimi sprawował rząd, utrzymanie rodzice zapewniali tylko do 14. roku życia. Dalej powinny utrzymywać się same $^{26}$.

Artykuł 61 stanowił, że Dzieci winny obu rodzicom uszanowanie i posłuszeństwo ${ }^{27}$. Iluzję, że zrównywało to pozycję ojca i matki, rozwiewał jednak następny podpunkt: Szczególniej jednak zostaja pod władza ojca ${ }^{28}$. Rozwiązaniem, które potwierdza pewne założenie, że ojciec powinien się bardziej opiekować synami, a matka córkami, jest podejście do spraw religii w przypadku małżeństw mieszanych. Do czternastego roku życia synowie wychowywani powinni być według wiary swojego ojca, a córki według wiary matki. Po ukończeniu 14 lat dzieci powinny decydować same ${ }^{29}$. Obowiązkiem dzieci była wszelka pomoc rodzicom, a ewentualne zarobki przypadały na własność rodzicom, a faktycznie w zarząd ojcu ${ }^{30}$. Karanie wedle uznania rodziców było czymś oczywistym. Wprowadzono jednak obwarowanie, by kara nieszkodliwa była dla zdrowia ${ }^{31}$. Wszelka ingerencja we władzę rodzicielską budziła wówczas ostre spory i dyskusje ${ }^{32}$, więc ów przepis należy uznać za nowoczesny. W przypadku osiągnięcia pełnoletności dzieci otrzymywały obowiązkową część dóbr ${ }^{33}$, z tym że córki w momencie wyjścia za mąż. Istniała jednak możliwość udowodnienia przed sądem marnotrawstwa dziecka, co sprowadzało utratę praw do majątku. Ów dowód przed sądem przeprowadzał ojciec.

Jedynie więc pełnoletni ojciec posiadał pełnię praw. Wychodzą tu jaskrawo wpływy prawa rzymskiego, w którym podobną, a nawet jeszcze mocniejszą pozycję miał ojciec rodziny, pater familias.

\section{Ojcostwo pod panowaniem austriackim}

Omawiając terytorium Galicji, pomijamy terytorium Rzeczpospolitej Krakowskiej, w której od 1810 r. obowiązywał Kodeks Cywilny Napoleona. Stosowne przepisy zostały wyłożone przy okazji omawiania sytuacji w Księstwie Warszawskim i Królestwie Polskim.

Galicja posłużyła Austrii za terytorium eksperymentalne. Tak jak w Prusach na zabranych ziemiach wprowadzono kodeks na samym końcu, tak w Galicji odwrotnie. Wyko-

\footnotetext{
${ }^{26}$ Ibidem, część II, tytuł II: „O wzajemnych prawach i obowiązkach rodziców i dzieci”, art. 557, 633, 639, 644, s. 78 .

27 Ibidem, część II, tytuł II: „O wzajemnych prawach i obowiązkach rodziców i dzieci”, art. 61, s. 77.

${ }^{28}$ Ibidem, część II, tytuł II: „O wzajemnych prawach i obowiązkach rodziców i dzieci”, art. 62, s. 77.

${ }^{29}$ Ibidem, część II, tytuł II: „O wzajemnych prawach i obowiązkach rodziców i dzieci”, art. 76, 84, s. 77.

${ }^{30}$ Ibidem, część II, tytuł II: „O wzajemnych prawach i obowiązkach rodziców i dzieci”, art. 121, 123, 168, s. 77.

31 Ibidem, część II, tytuł II: „O wzajemnych prawach i obowiązkach rodziców i dzieci”, art. 86, s. 77.

32 Por. Jerzy Śliwowski, Kodeks Karzący Królestwa Polskiego. Historia jego powstania i próba krytycznej analizy, Warszawa 1958, s. 96-97.

${ }^{33}$ G. Bałtruszajtis, J. Kolarzowski et al., op. cit., cz. II, tytuł II: „O wzajemnych prawach i obowiązkach rodziców i dzieci", art. 210 s. 76 , art. 392, s. 77.
} 
rzystano nowe nabytki terytorialne dla sprawdzenia w praktyce nowego prawa zwanego Kodeksem Cywilnym Zachodniogalicyjskim wprowadzonego w całej Galicji w 1797 r. Sankcję cesarską Franciszka I po niewielkich zmianach otrzymał kodeks w 1811 r., wprowadzony został w życie w roku następnym we wszystkich krajach austriackich pod nazwą Allgemeines Burgerliches Gesetzbuch ${ }^{34}\left(\mathrm{ABGB}^{35}\right.$, Kodeks Cywilny Austriacki). Obowiązywał bez większych zmian do I wojny światowej. Przyjmuje się, że ABGB miał charakter nowoczesny. Obejmując całość prawa cywilnego, nie był zbyt obszerny, bo liczył tylko 1502 artykuły. Pozbawiony był kazuistyki typowej dla kodeksu pruskiego (liczącego 19187 artykułów), przepisy w nim sformułowane były wyrażone jasno i zwięźle.

ABGB pozostawał pod silnym wpływem prawa rzymskiego i filozofii prawa natury. $\mathrm{Z}$ tego pierwszego uwzględniał systematykę oraz terminologię. Choć prawo rzymskie nadal było pewnym wzorem i punktem odniesienia, uważano, że ponad prawem pozytywnym istnieje prawo naturalne niezależne od człowieka, odwieczne i niezmienne, bo wypływajace z samej natury ludzkiej ${ }^{36}$. Kodeks austriacki powstawał przez wiele lat. Na jego kształt wpłynęła zarówno Maria Teresa w swoich instrukcjach z 1753 i 1772 r., jak i dający sankcję Franciszek II, ale przede wszystkim wybitni prawnicy Karol Martini (1726-1800) oraz Franciszek Zeiller (1751-1828). Zeiller, odpowiedzialny za ostateczny kształt kodeksu, wykreślił z wersji zachodniogalicyjskiej większość prawnonaturalnych sformułowań uzasadniających przepisy. Miały na to wpływ upowszechnione już wówczas poglądy Kanta odróżniające prawo od moralności ${ }^{37}$. Jednak nie zmienił on wymowy zasadniczych przepisów kodeksu, tak że może on zostać uznany za twór ideologii prawa natury. Co ma szczególne znaczenie - przed ostatecznym wprowadzeniem kodeksu poddano go dyskusji publicznej organizowanej przez komisje krajowe. Niektóre z postulatów uwzględniono, co zbliżyło zapisy kodeksu z prawem zwyczajowym ${ }^{38}$. Poza wstępem obejmował trzy księgi: o prawie osobowym, prawie rzeczowym, o przepisach wspólnych dla praw osobowych i rzeczowych. Przepisy dotyczące prawa małżeńskiego oraz rodzinnego znalazły się w księdze pierwszej.

Małżeństwo było postrzegane jako ,źródło stosunków familijnych”. Mimo pozornej równości wobec prawa, jeśli chodzi o prawo małżeńskie kodeks precyzował jednoznacznie, do kogo należą decyzje w rodzinie: Mąż jest głowa familii. Jako takiemu stuży szczególniej prawo kierowania gospodarstwem domowym, lecz także ma obowiazek dawać żonie stosowne do swego majątku przyzwoite utrzymanie i bronić ja w każdym przypadku $u^{39}$. Także na ziemiach austriackich była potrzeba zgody ojca, jeśli chcący się pobrać

${ }^{34}$ Pełna nazwa: Allgemeines Bürgerliches Gesetzbuch für die gesamten Deutschen Erbländer der Osterreichischen Monarchie.

${ }^{35}$ Ustalony zwyczajem, stosowany powszechnie w podręcznikach prawa skrót. Między innymi Sójka-Zielińska, Szczaniecki.

${ }^{36}$ K. Sójka-Zielińska, op.cit., s. 43.

37 Ibidem, s. 44.

38 J. Bardach, B. Leśnodorski, M. Pietrzak, op.cit., s. 421.

39 ABGB, 1811, część I, rozdział II: O małżeństwie, art. 91, w: G. Bałtruszajtis, J. Kolarzowski, M. Paszkowska, K. Rajewski, Wybór źródet do historii prawa sądowego czasów nowożytnych, Warszawa 1996, s. 95. 
byli małoletnimi. Tutaj jednak władza ojcowska kończyła się znacznie wcześniej. Pełnoletniość osiągało się wraz z ukończeniem 20. roku życia ${ }^{40}$. Podkreślona bardzo silnie była nierozerwalność małżeństwa katolickiego, nawet jeśli tylko jeden z małżonków był tego wyznania. W stosunku do rodziców dzieci winny okazywać szacunek i posłuszeństwo. Kierować dziećmi winni rodzice w porozumieniu ze sobą ${ }^{41}$. Kodeks przyznawał rodzicom prawo do wyszukiwania i sprowadzania pod przymusem zbiegłych z domu dzieci, co zarazem pokazuje, że takie wypadki mogły zdarzać się dość często. Znalazły się też ustępy o dopuszczalności kary, ale umiarkowanej i nieszkodliwej dla zdrowia. W dodatku pojawiły się konkretne przypadki, w których taka kara może być zastosowana. Mimo że bardzo są one ogólne i prawie każde zachowanie dałoby się podciągnąć pod któreś z nich, to jednak samo zastrzeżenie jest pewnym ograniczeniem. Dzieci można karać, kiedy są: nieobyczajne, niepostuszne, lub jeżeli spokojność, porządek domowy zakłócaja $a^{42}$.

Mimo że władza ojcowska była według ABGB bardzo silna, to jednak na tle pozostałych kodyfikacji wydaje się ona najsłabiej podkreślona. Przykładowo przepisy dopuszczające ściganie, nadając prawo, jednocześnie ograniczały władzę ojcowską w tym sensie, że ingerowały głębiej niż w innych kodeksach w to, co wolno albo nie wolno ojcu.

\section{Księstwo Warszawskie i Królestwo Polskie}

Zanim zostanie omówione prawo cywilne w Księstwie Warszawskim i Królestwie Polskim, warto kilka słów poświęcić sytuacji na ziemiach niewchodzących w skład tych tworów politycznych, ale wchodzących w skład Imperium Rosyjskiego.

W dziewięciu zachodnich guberniach Cesarstwa, a więc na ziemiach dawnego Wielkiego Księstwa Litewskiego oraz w guberni kijowskiej i wołyńskiej zaprowadzono system, w którym duża lokalna swoboda, gwarancje ustroju stanowego, poszanowanie religii rzymskokatolickiej połączono ze scentralizowaną administracją. Poszanowanie odrębności obejmowało także prawo. Obowiązywał na tych ziemiach III Statut litewski z 1588 r., a jego moc potwierdziły ukazy carskie z lat 1796 i 1801 i dekrety senackie z 1819 i 1822 r. $^{43}$

Odrębną autonomię posiadał obwód białostocki, który był przyłączony do Rosji w wyniku traktatu w Tylży. Tam obowiązywało w tym zakresie prawo pruskie. Na pozostałym terytorium prawa litewskie i polskie uchylono dopiero w 1840 r., ${ }^{44}$ wprowadzając $\mathrm{w}$ to miejsce kodyfikację rosyjską. Prawo statutu charakteryzuje się jak na ówczesne czasy dość wyważonym statusem względem siebie obojga rodziców. Ojciec miał przewagę, ale nie była ona zbyt mocno akcentowana. Istniało także szereg praw gwarantujących

\footnotetext{
s. 92.

${ }^{41}$ Ibidem, część I, rozdział III O prawach między rodzicami a dziećmi, art. 144, s. 96.

42 Ibidem, część I, rozdział III O prawach między rodzicami a dziećmi, art. 145, s. 96, 97.

43 J. Bardach, B. Leśnodorski, M. Pietrzak, op. cit., s. 372.

${ }^{44}$ S. Płaza, op. cit., s. 54.
}

${ }^{40}$ Ibidem, część I, rozdział I O prawach odnoszących się do osobistych przymiotów i stosunków, art. 21, 
kobietom pewną niezależność. Statut zabraniał zmuszania kobiet do małżeństwa wbrew ich woli i, co ciekawe, tyczyło się to niewiast wszystkich stanów ${ }^{45}$. Wolno było kobiecie wyjść za mąż wbrew woli krewnych, wtedy jednak traciła prawo do wyprawy ${ }^{46}$. Zarówno ojciec, jak i matka byli szczególnie chronieni, a targnięcie się na nich przez dzieci było karane śmiercią. Gdyby zaś napaść dzieci na rodziców zakończyła się śmiercią któregokolwiek z nich, wtedy śmierci towarzyszył szereg okrutnych tortur:

Ustawujemy gdyby syn abo córka oyca abo matkę swa umyślnie z jekijey zapamiętatości zabił, i jakimkolwiek obyczaiem rodzica swego o gardto przyprawit. Tedy takowy syn albo dziewka, która przyczyna swa o gardło rodzica swego przyprawi, nie tylko gardłem ma być karan, ale i poczciwość, i wszystkie imiona, i maiętność traci, na insza bracia $i$ siostry abo bliskich swych, zwlaszcza tego uczynku niewinnych. A takowa karnością, śmiercia haniebna ma karan być, po rynku wożac kleszczami ciało targać, a potym $w$ miech skórzany, wsadziwszy do niego psa, kura, węża, kotkę, i to wszystko pospotu $w$ miech wsadziwszy zaszyć, i gdzie naygłębiej do wody utopićc ${ }^{47}$.

Ten rodzaj kary hańbiącej dotyczył także wszelkich pomocników w zbrodni. Kary takie znajdowały zastosowanie w przypadkach szczególnego naruszenia świętości, zamachu na rzeczy powszechnie otaczane najwyższą czcią. Zaliczenie rodziców do katalogu rzeczy podlegających szczególnej ochronie świadczy o ich pozycji w stosunkach rodzinnych.

Kara cielesna była czymś oczywistym, jednak do momentu trwałego okaleczenia któregokolwiek z członków bądź zabicia dziecka. Kary jednak za zabicie dzieci były wielokrotnie łagodniejsze. Za umyślne zamordowanie dziecka przez którekolwiek z rodziców groził rok i sześć tygodni w wieży i kilkakrotna publiczna spowiedź. Samo zaś uderzenie któregokolwiek z rodziców powinno być karane śmiercią.

Oboje rodzice mieli prawo wyrzec się dzieci, co powodowało utratę przez nie wszelkich praw do nazwiska i majątku. Choć było to zawarowane dla kilku przypadków, ogólne sformułowania $\mathrm{w}$ praktyce dawały nieograniczone do tego prawo ${ }^{48}$.

W niemal wszystkich przepisach, nawet jeśli w tytule wymienia się ojca, w tekście przepisu okazuje się, że prawa takie posiada również matka. Trzeba więc stwierdzić, że była to rzecz wyjątkowa i w połączeniu z innymi przepisami chroniącymi białogłowy pozycja matki wedle prawa staropolskiego była dość silna. Zarówno prawo pod tym względem w Rosji, jak i na zachodzie Europy silniej zaznaczało pozycję ojca. Trzeba jednak pamiętać, że mimo silnej pozycji kobiet w prawie staropolskim, zwłaszcza mężatek i wdów, sytuacja ta była daleka od równouprawnienia.

Prawo cywilne w Księstwie Warszawskim i Królestwie Polskim opierało się na Kodeksie Napoleona z 1804 r. Uchodzący za arcydzieło sztuki legislacyjnej był kompilacją prawa zwyczajowego północnej Francji, prawa rzymskiego, prawa kanonicznego daw-

\footnotetext{
${ }^{45}$ III Statut litewski, III, 39, w: S. Godek, M. Wilczek-Karczewska, Historia ustroju i prawa w Polsce. Wybór źródel, Warszawa 2006, s. 376.

46 Ibidem, Statut III, XI, 13, s. 385.

47 Ibidem, Statut III, XI, 7, s. 383.

${ }^{48}$ Ibidem, Statut III, VII, 7, s. 379-380.
} 
nych ordonansów królewskich i prawa rewolucyjnego. Umiejętne połączenie starych norm z nowymi racjonalnymi postulatami prawa natury, zwięzły precyzyjny język, zjednały mu uznanie w wielu częściach Europy. Wprowadzony został w Księstwie 1 maja 1808 r., a później w 1825 r. po dokonaniu niewielkich zmian jako Kodeks Cywilny Królestwa Polskiego.

O ile w innych kwestiach uważany za bardzo nowoczesny i postępowy, o tyle w prawie rodzinnym Kodeks Napoleona kreował model patriarchalny najmocniej spośród omawianych wcześniej kodeksów. Przywracał władzę ojcowską zniesioną przez rewolucyjny dekret z 28 VIII 1792 r. ${ }^{49}$ Pozycja żony charakteryzowała się głębokim upośledzeniem. O kobiecie zamężnej mówiono, że jest „wieczyście małoletnia”, przez co rozumiano niezdolność do czynności prawnych bez zgody męża. Artykuł 212 mówił, że Małżonkowie winni sobie nawzajem wierność, wsparcie i pomoc ${ }^{50}$. Ale artykuł 213 zaraz precyzował, że mąż winien żonie obronę, a żona postuszeństwo mężowi ${ }^{51}$. Posłuszeństwo dotyczyło również zamieszkania. Kobieta powinna podążać za mężem. Gdziekolwiek zechce on zamieszkać, powinna zamieszkać razem z nim. Także w sprawie rozwodu nie istniało równouprawnienie. Mężczyzna mógł się rozwieść z żoną z powodu cudzołóstwa żony, ale ta tylko wtedy, gdy mąż nałożnicę trzymał we wspólnym domu ${ }^{52}$. Podobno na prawo małżeńskie miał osobisty wpływ sam Napoleon, który na jednym z posiedzeń w Radzie Stanu miał powiedzieć: „natura uczyniła z kobiety naszego niewolnika”. Gdy idzie o zezwolenie na małżeństwo, syn przed 25. rokiem życia, córka przed 21. rokiem musieli uzyskać zgodę rodziców, a w przypadku różnicy zdań wystarczyła zgoda samego ojca $^{53}$. Nawet po przekroczeniu ustalonego wieku należało jeszcze ubiegać się o zgodę 3 razy w miesięcznych odstępach. Dopiero wtedy bez uzyskania zgody mogło dojść do ślubu. Po skończeniu lat 30 wystarczyło czekać miesiąc po pierwszej odmowie. Ojciec miał prawo okresowego więzienia swoich dzieci. Aby uwięzić małoletnich po ukończeniu 16 lat, musiał pytać o zgodę prezesa lokalnego trybunału. Dzieci powinny szanować ojca i matkę, ale władza nad dziećmi w trakcie małżeństwa należała do ojca. Wyjątek oddający ducha czasu był dla synów, którzy skończyli 18 lat. Ci mogli wbrew ojcu zaciągnąc się do wojska. Małoletniość poza prawem do małżeństwa kończyła się w momencie ukończenia 21. roku życia.

Kodeks Napoleoński napotkał pewne trudności na terenach polskich ze względu na sekularyzację małżeństwa, a także karę więzienia dla dzieci. Obie rzeczy zmieniono w Kodeksie Cywilnym Królestwa Polskiego (1825 r.), wprowadzając część postulatów Kościoła katolickiego. Małżeństwu przywrócono formę wyznaniową, ale nadal właściwe dla niego były sądy świeckie ${ }^{54}$. Zmienił to później Mikołaj I w 1836 r., wprowadzając

\footnotetext{
${ }^{49}$ K. Sójka-Zielińska, op. cit., s. 90.

${ }^{50}$ Kodeks Napoleona Księga I, rozdział V O małżeństwie, art. 212, w: G. Bałtruszajtis, J. Kolarzowski, et al., op. cit., s. 113 .

51 Ibidem, art. 213, s. 112.

52 Ibidem, rozdział VI O rozwodzie, art. 229, 230, s. 114.

53 Ibidem, rozdział V O małżeństwie, art. 148, s. 112.

${ }^{54}$ S. Płaza, op. cit. , s. 52.
} 
„Prawo o małżeństwach” i przywracając w pełni wyznaniową formę małżeństwa, oddając sprawy małżeńskie wyłącznej kompetencji sądów duchownych czterech uznanych wyznań: rzymskokatolickiego, prawosławnego, protestanckiego, unickiego. W Kodeksie Cywilnym Królestwa Polskiego zniesiono areszta, a przywrócono ius castigandi, czyli prawo karcenia domowego bliższe tradycji polskiej.

Ciekawa dyskusja nad władzą rodzicielską rozegrała się przy pracy nad projektem Kodesu Karzącego Królestwa Polskiego. Projekty artykułów 388 i 389 zakładały łagodne kary dla rodziców nadużywających karności domowej ${ }^{55}$. Członkowie Rady Stanu jednak odrzucili oba artykuły. Za najzagorzalszego przeciwnika uchodził Stanisław Staszic, który uważał, że pozwolenie na zaskarżanie przez dzieci byłoby pogwałceniem naczelnej zasady posłuszeństwa dzieci względem swych rodziców. W KCKP ${ }^{56}$ wprowadzono ochronę dzieci wobec rodziców stosujących środki karności szkodliwe zdrowiu dzieci. Artykuł $339^{57}$ dopuszczał nawet, by sąd ziemski powierzył komuś innemu opiekę nad dziećmi, na koszt winnych rodziców. Było to przewidziane jednak dla przypadków skrajnych.

Władza ojcowska w Księstwie Warszawskim i Królestwie Polskim była w świetle prawa niezwykle silna. Pod przejrzyście skonstruowanymi przepisami kryła się brutalnie sformułowana władza męża i ojca nieidąca w parze ze specjalnymi względami wobec żony i dzieci. Przywrócenie przedrewolucyjnej pozycji ojca nie wiązało się z przywróceniem pewnego specyficznego, specjalnego szacunku, jakim cieszyła się mężatka. Nic dziwnego, że prowadziło to do wzrostu niezadowolenia wśród kobiet. W 1904 r. mała grupka kobiet spaliła symbolicznie egzemplarz Kodeksu Napoleona pod kolumną Vendome w Paryżu ${ }^{58}$.

55 J. Śliwowski, Kodeks Karzący Królestwa Polskiego (1818 r.). Historia jego powstania i próba krytycznej jego analizy, Warszawa 1958, s. 96.

56 Kodeks Cywilny Królestwa Polskiego.

57 J. Śliwowski, op. cit., s. 97, w przypisach.

${ }^{58}$ K. Sójka-Zielińska, Wielkie kodyfikacje cywilne XIX wieku, Warszawa 1973, s. 102. 